\title{
The Place of Financial Markets in the Development Process: Evidence from Nigeria
}

\author{
Ehigiamusoe Uyi Kizito \\ National Institute for Legislative Studies, National Assembly, Abuja-Nigeria \\ ehiuyikizexcel@yahoo.com
}

\begin{abstract}
The paper examines the place of financial markets in the development process in Nigeria. The paper used descriptive approach and discovered that financial markets play fundamental role in the development process. However, the overall performance of the Nigeria's financial market despite some expansion in recent times has been below its potential. In particular, as propellers of economic development, the markets have not been able to meet their goals such as accelerating industrial development, promoting the rate of investment, generating employment opportunities, providing services that help accelerate poverty reduction, promoting human capital development, and accelerating agricultural productivity. Some of the challenges confronting the Nigeria's financial markets include; dearth of instruments and lack of market breadth and depth, the oligopolistic structure of the markets, dependence on government, slow growth of the secondary market and information gap and asymmetry. It was therefore recommended that the financial markets should be reformed and effectively harnessed as tools of economic development, and policy makers should create the enabling environment for financial markets to thrive to propel Nigeria to the path of development with a view to achieving Vision 20:2020.
\end{abstract}

Keywords: Financial market, Economic development, Economic growth, Vision 20:2020

\section{Introduction}

During the past decades, much emphasis has been placed on understanding the role of the financial sector, in part because earlier lessons were learned, and in part because of the financial crises of the 1990s and late 2000s. Understanding the role of the financial sector has increased markedly, but research and insights continue to mount. Consequently, some have turned to "governance issues" as "the key" to development, but lessons about the importance, and key role, of the financial sector in development have certainly been learned. We have long known about the importance of the financial sector in supporting an efficient allocation of resources and economic growth. However, it has not been so well recognized that as economies develop, the financial system becomes increasingly important either as a facilitator of economic growth (if it is performing its functions and developing with the rest of the economy) or as an inhibitor (if it remains underdeveloped). ${ }^{1}$ Financial Markets play an important role in the mobilization of financial resources for long-term investment through financial intermediation. Well functioning financial markets are very crucial for the promotion of global integration. An efficiently functioning domestic financial market can better position a country's competitiveness in the market for global capital ${ }^{2}$. A Financial market is a specialized market that is responsible for channeling financial resources from the surplus units (savers) to the deficit units (those who need additional funds) to carry out some forms of economic activities. It is made up of financial institutions that receive financial resources from the surplus units of the economy in the forms of savings and transfer them to the deficit units through lending activities. This role of transferring financial resources from the surplus units to the deficit units is what is referred to as financial intermediation. The set of financial institutions in the financial market are referred to as financial intermediaries. The financial market is segmented into two, namely, the money and capital markets. While the money market deals in short-term funds, the capital market deals in longterms loan able funds (Anyanwu, 1996).The basis of distinction between the money and capital market lies in the degree of liquidity of instruments bought and sold in each of the markets. The capital market is the constituent of the financial markets that facilitates the mobilization of long-term investment capital for the financing of business enterprises as well as government long-term investment projects. It offers an opportunity for both private business and government to mobilize huge amount of financial resources from the public through the sale of financial securities. The capital market is further divided into the

\footnotetext{
${ }^{1}$ Krueger (2006) Financial Markets and Economic Growth

2 Senbet and Otchere, (2005) Financial Sector Reforms in Africa: Perspectives on Issues and Policies.
} 
primary and the secondary markets. The primary market deals with the trading of new securities, while the secondary market facilitates the buying and selling of securities that are already in the hands of the investors.

The existence of money market facilitates trading in short-term debt instruments to meet short-term needs of large users of funds such as governments, banks, and similar institutions. Money market plays a key role in bank's liquidity management and the transmission of monetary policy. By providing the appropriate instruments and partner for liquidity trading, the money market allows the refinancing of short and medium term positions and facilitates the mitigation of business liquidity risks. The banking system and the money market represent the exclusive setting in which monetary policy operates. A developed, active, and efficient interbank market and the money market enhance the efficiency of central bank's monetary policy and the transmission of its impulses into the economy. Thus, the development of the money market smoothen the progress of the financial intermediation and boost lending to the economy, and improves the country's economic and social welfare. According to Fischer (2003), the textbooks tell us that the role of the financial system is to intermediate between lenders and borrowers, providing a menu of saving vehicles with differing risk and return characteristics, and helping investors find the financing they need, taking into account the returns and risks on the projects they wish to undertake. In practice, there are two views on the importance of the financial system during development. The first view is that the financial sector does not matter very much, and that any correlation between financial development and growth is a result of growth leading development. ${ }^{3}$ This is a view many analyst held in the 1980s. So did Robert Lucas, who in his celebrated 1988 paper on development said:

"I will... be abstracting from all monetary matters, treating all exchange as though it involved goods-forgoods. In general, I believe that the importance of financial matters is very badly over-stressed in popular and even much more professional discussion and so is not inclined to be apologetic for going to the other extreme.4"

The second view is that an efficient financial system is key to development. In his classic, Lombard Street, published in 1873, Walter Bagehot argued that it was England's efficient capital market that made the industrial revolution possible. However, the most important and thorough early contribution on financial development and economic development came from Joseph Schumpeter in 1934. He contended that financial development causes economic development - that financial markets promote economic growth by funding entrepreneurs and in particular by channeling capital to the entrepreneurs with high return projects. He developed his case in vivid language:

"The banker... is not so much primarily a middleman in the commodity 'purchasing power' as a producer of this commodity... He stands between those who wish to form new combinations and the possessors of productive means. He is essentially a phenomenon of development, though only when no central authority directs the social process. He makes possible the carrying out of new combinations, authorizes people, in the name of society as it were, to form them. He is the ephor [overseer] of the exchange economy"5

Nigerian has abundant human, material and natural resources, yet, the pace of economic development has been rather slow, and others have argued that the economy is experiencing underdevelopment when compared to the 1960s and 1970s (Ekpo, 2008). The Nigerian economy has experienced all phases of a typical business cycle. What is disturbing is that the boom(s) - commodity, financial and mineral resources, were not linked to the real sector. Each boom came and went, yet the economy remained backward and undeveloped (Ekpo, 2008). From political independence in 1960 till date, various regimes and their policy makers attempted to managed the economy to ensure full employment, output and price stability. Advocates of financial market-induced economic growth in Nigeria believe that the financial markets promote economic growth ${ }^{6}$ while opponents of the above deposition claim that the Nigerian financial market is faced with myriads of challenges that could hinder economic growth rather than

\footnotetext{
${ }^{3}$ Fischer (2003) The Importance of Financial Markets in Economic Growth

${ }^{4}$ Lucas (1988) "On the Mechanics of Economic Development." p6

${ }^{5}$ Schumpeter (1934. Theorie der Wirtschaftlichen Entwicklung) p74

${ }^{6}$ Jalloh (2009) The Role of Financial Markets in Economic Growth
} 
promote it ${ }^{7}$. The question that comes to mind is: Does the Nigerian financial markets promote or hinder economic growth and development? This paper is out to investigate the place of financial markets in the development process with emphasis on Nigeria. As the theoretical debate on the relationship between financial markets and economic development in Nigeria continues, works that are more empirical are needed to establish the direction of the relationship. This study is an attempt to close this gap. Following this introduction, the remaining part of the paper is divided into four parts. Section two deals with empirical issues. Section three investigates the role of financial markets in economic growth and development, while Section four presents an overview and challenges of the Nigerian financial markets. The last part of the paper contains conclusion and recommendations.

\section{Empirical Issues}

The two variables in this study are Financial Markets and Economic Development. A Financial market is a specialized market that is responsible for channeling financial resources from the surplus units (savers) to the deficit units (those who need additional funds) to carry out some forms of economic activities. It is made up of financial institutions that receive financial resources from the surplus units of the economy in the forms of savings and transfer them to the deficit units through lending activities. This role of transferring financial resources from the surplus units to the deficit units is what is referred to as financial intermediation. The set of financial institutions in the financial markets are referred to as financial intermediaries. In broad usage, the financial markets consist of; Capital market (which provide long term funds and is made up of Stock markets and Bond markets), Money markets, (which provide short term debt financing and investment), Derivatives markets, (which provide instruments for the management of financial risk), Futures markets, (which provide standardized forward contracts for trading products at some future date), Commodity markets, (which facilitate the trading of commodities), Insurance markets, (which facilitate the redistribution of various risks,), and Foreign exchange markets, (which facilitate the trading of foreign exchange). On the other hand, Economic Development is the process of improving the quality of all human lives. Three equally important aspects of development are; the raising of people's level of living (their incomes and consumption levels of food, medical services, education, etc,) through relevant economic growth process; creating conditions conducive to the growth of people's self-esteem through the establishment of social, political, and economic systems and institutions that promote human dignity and respect; and increasing people freedom by enlarging the range of their choice variables, as by increasing varieties of consumer goods and services ${ }^{8}$. Have the Nigeria's Financial Markets (Money and Capital markets) enhance or hinder the process of improving the quality of all human lives in the country? If the Nigeria's Financial Markets are functioning effectively and efficiently, what have been their impacts on poverty, unemployment and inequality? If their impacts have reduced all these three variables from high levels, then, financial markets have brought about development in the country. However, if one or two of these central problems have been growing worse, especially if all the three have, it would be strange to call the result 'development' even if per capita income doubled ${ }^{9}$. Several studies have been conducted on the relationship between financial intermediation and economic growth. The financial system has long been known in the literature to play an important role in the economic development of a country. This was demonstrated by McKinnon (1973) and Shaw (1973) who showed that financial sector is a catalyst to economic growth if it is developed and healthy. However, the financial market is divided into two major markets namely capital and money markets. Some earlier studies have examined the relationship between the capital market and economic growth in Nigeria and majority of these studies have showed that capita market promotes economic development (Zervos, 1998, Obstfeld, 1995, and Levine, 1996). On the other hand, theoretical evidences are divided as to the relationship between money market and economic growth. Greenwood and Jovanovic (1990), Ajakaiye (2002), and Adebiyi (2005) show that financial intermediation promotes economic growth, while Lucas (1988), Omoruyi (1991), Ebhodaghe (1996), Soyibo et al (1997), Sobodu and Sobodu (1999), suggest otherwise.

Goldsmith (1969), using a cross-section of 80 countries during the period 1960-1989 found that financial development promotes economic growth when other growth conditioning variable are taken into

${ }^{7}$ Olofin and Udoma (2011) Financial Structure and Economic Growth in Nigeria: A Macro econometric Approach

\footnotetext{
${ }^{8}$ Todaro and Smith (2009) Economic Development $10^{\text {th }}$ Edition, New York

${ }^{9} \mathrm{Ibid}$
} 
account. McKinnon (1973) provides country-specific evidence in a study that focuses on the economies of Argentina, Brazil, Chile, Germany, Indonesia, Korea, and Taiwan during the post-World War II period. Examining the relationship between adopted financial policies and economic growth in these countries, McKinnon concluded that better functioning financial system aid faster growth. Related cross-country studies by Easterly \& Levine (1997), lend credence to financial development having a positive effect on long-run economic growth. King and Levine (1992), Levine and Zervos (1998) gave empirical evidence supporting the hypothesis that financial development enhances economic growth. With respect to Africa economies, Gelbard and Leite (1999) provides evidence that although there remains much to be done, financial reforms in many adjusting African countries has contributed positively to economic growth (Saibu et al 2009). In another studies Senhadji et al (2000) employ a dataset comprising 159 countries over 1960-1999 and their analysis confirm a strongly positive and statistically significant relationship between financial depth indicators covering banking system and securities market and economic growth. Shan et al (2002) use a Granger causality procedure to investigate the relationship between financial development and economic growth for nine OECD countries and China by estimating a vector auto regression (VAR) model. The results of their study show that five out of ten countries have a bilateral Granger causality; three of them have reverse causality with economic growth leading to financial development while two countries do not have a causal effect at all. Schoar (2009) agrees that a competitive banking sector is necessary in facilitating firm growth and competition, and that equity markets constitute only a small portion of overall financing in developing countries. She underscores that scale was important for banks, and tiny banks will not garner sufficient capital to finance small businesses for expansion. In particular, the banking sector should be established and tailored to improve the real economy and, as a tool to create jobs and opportunities. Schoar (2009) proposes a two-tier banking system where one tier consist of small banks that serve basic financial needs and the other tier should consist of larger banks that serve medium firms that can create jobs for many others and will grow to large scales. Agha, et al (2005) in a study of the transmission mechanism of monetary policy in Pakistan asserted that the role of bank lending is prominent because of the dominance of the banking sector. Other factors that might have enhanced the banks' role included financial reforms, market-based credit allocation and crowding-in of private sector credit due to the decline in fiscal dominance. The extant literature shows that the bank-lending channel is an important medium through which monetary policy permeates the real sector of the economy. Therefore, in the pursuit of price stability by monetary authorities, the consideration of the impact of lending on monetary aggregates is a necessary condition for attaining macroeconomic stability. A major implication of the credit view is that monetary policy will have a greater effect on expenditure by smaller firms, which are more dependent on bank loans than it will on large firms, which can access the credit markets directly through stocks and bond markets.

According to Levine (2004), the form and function of financial institutions are country-specific and would rely on the legal and political system as well as the evolving economic activities. He, therefore, argues that a suitable policy objective would be to construct laws, regulations, and institutions that would create an enabling environment to engender competition among financial institutions in the provision of essential credit, risk, and liquidity services to the real economy. He states that although the stock markets do not provide much capital to firms, they provide complementary risk diversification services that facilitate the efficient allocation of credit. Zingales (2009) favors a more fragmented, competitive banking sector, which according to him creates a fluid transition from a pure banking system to a system that relies both on markets, and banks, as economic activities expand. To Thoma (2009), developing countries require not only small banks and microfinance institutions that support small borrowers, but could also do with relatively sophisticated financial instruments such as hedging price risks through futures markets, insuring against crop failures, purchasing farm equipment through pooling arrangements, and managing the problem brought about by seasonality. He acknowledges inadequate information on the financial history and worthiness of potential borrowers as a challenge and that small banks were better positioned to collect such information. Along a line Patrick (1966) examined the causal relation between financial development and economic growth and found that there is a unidirectional causality between financial development and economic growth, the result portrays a supply-leading association but at the later phase, the direction of causality is inverted to demand-following relationship. The cross-country literature on the relationship between financial development and economic growth is vast - and most studies show that financial development unambiguously and positively affects economic growth (Levine, 1997; Agha et al., 2005). Favara, (2003) using a larger sample and a longer time finds that the relationship between financial development and economic growth is weak and that the exogenous component of financial development does not spur economic growth. He also finds that the link between financial development and economic development is non-linear (being strongest for middle-income 
countries). ${ }^{10}$ According to Muhammad et al (2003) an organized and managed stock market stimulate investment opportunities by recognizing and financing productive projects that lead to economic activity, mobilize domestic savings, allocate capital proficiency, help to diversify risks, and facilitate exchange of goods and services (Caporale, 2004). Undoubtedly, stock markets are expected to increase economic growth by increasing the liquidity of financial assets, make global and domestic risk diversification possible, promote wiser investment decisions, and influence corporate governance, i.e., solving institutional problems by increasing shareholders' interest/value (Osei, 2005). In addition to the above, stock markets are best indicator to forecast future economic activity and describe actual casual effect between future economic growth and stock prices. On the contrary, the relationship between stock market development and real economic growth can be explained, as any change in stock market will eventually change the cost of rental capital. If the firm is cost of borrowing become high as compared to investment, it slows down the growth of the economy ${ }^{11}$.

Umar (2010) in his empirical investigation of Stock Markets, Banks and Economic Growth: A Time -Series Evidence from South Africa suggests that in the long run, there is evidence of bidirectional causality between financial development and economic growth using the banking system proxy by Bank Credit to Private sector (BCP). While, when stock markets variables are used that is Turnover Ratio (TR) and Value of shares Traded (VT), the results indicate unidirectional causality from economic growth to stock market system. The Impulse response functions (IRFs) and variance decompositions (VDCs) indicate that financial development (BCP,TR, and VT) have short-run impact on economic growth at the immediate year of initial shocks and VDCs shows that all the indicators for financial development contain some useful information in predicting the future path of economic growth. Meanwhile, SVAR results indicate little evidence that finance promote economic growth in the long run. Pardy (1992) in his seminal work has argued that in less developed countries capital markets are able to mobilize domestic savings and allocate funds more efficiently. Spears (1991) reported that in the early stages of development, financial intermediation induced economic growth. Similarly, Atje and Jovanovic (1993) concluded that stock markets have long-run impacts on economic growth and it was found that stock markets manipulate economic growth through a number of channels such as liquidity, risk diversifications, acquisition of information about firms, corporate governance and savings mobilization (Levine \& Zervos, 1998).

Kolapo \& Adaramola (2012) examined the impact of the Nigerian capital market on its economic growth from the period of 1990-2010 and submitted that the performance of the stock market is an impetus for economic growth and development. Applying Johansen co-integration and Granger causality tests, results of their study showed that the Nigerian capital market and economic growth are co-integrated. This implies that a long run relationship exists between capital market and economic growth in Nigeria. This is a clear indication of the relative positive impact the capital market plays on the economic growth of the country. The evidence from this study reveals that the activities in the capital market tend to impact positively on the economy. It was recommended therefore that the regulatory authority should initiate policies that would encourage more companies to access the market and be more proactive in their surveillance role in order to check sharp practices, which undermine market integrity and erode investors' confidence. From the review of literature above, several research works have been done on the relationship between the capital market and economic growth, though there is no consensus among the researchers as whether capital market foster or inhibit economic growth in Nigeria. Similarly, some research works have been done on the relationship between money market and economic growth in Nigeria, though consensus among researchers as to the direction of the relationship is still lacking. However, the financial markets consist of the money and capital markets. Research works that investigate the role financial markets (money and capital markets) play in the development process is still scanty. This research work intends to fill this gap by examining the place of financial markets in the development process in Nigeria.

\section{The Role of Financial Markets in Economic Growth and Development}

The role of financial intermediation in the economic growth process was recognized as far back as the 17th century when Walter Bagehot, in his classic Lombard Street, argued that it was England's efficient capital markets that made the industrial revolution possible. Centuries later, modern day economists hold largely the same view that access to investment capital, through well functioning financial markets, is

\footnotetext{
${ }^{10}$ Stanley Fischer (2003) The Importance of Financial Markets in Economic Growth

${ }^{11}$ Ibid
} 
crucial for growth and development, particularly in capital-scarce developing countries. They maintained that stock markets facilitate the pricing and diversification of risk, aid in the price-discovery process of financial assets and enhance the operations of the domestic financial system. ${ }^{12}$ By mobilizing savings from surplus spending economic units to the deficit spending units, a capital market provides avenues for effective and optimal utilization of funds for long-term investment purposes. In addition, capital markets encourage the inflow of foreign capital by creating a platform for foreign companies or investors to invest in domestic securities; provide needed seed money for capital development; and act as a reliable medium for broadening the ownership base of family-owned and dominated firms.. Therefore, as Nigeria seeks to join the ranks of the 20 most developed economies by year 2020, there is need for the nation's capital market to evolve to a higher level of sophistication and depth to provide additional investment capital to meet the rapid expansion. The expansion in stock market activity across the country is necessary in view of the significant role financial markets play in the economic growth process. It is in this light that the stock exchange market acts as a barometer for economic performance, in the sense that it assists to allocate the necessary capital needed for the consistent growth of an economy.13 Indeed, a number of economists have argued that the determination of the overall growth of an economy depends on how efficiently the stock market performs in its allocative functions of capital. When the stock market mobilizes savings, it simultaneously allocates a larger portion of the savings to firms with relatively high prospects as indicated by their returns and level of risk. The significance of this function is that capital resources are channeled by the mechanism of the forces of demand and supply to those firms with relatively high and increasing productivity, thus enhancing economic expansion and growth. Again, the stock market, being a major component of Nigeria's financial sector, serves a pivotal role in contributing to economic growth in this capacity ${ }^{14}$. As much as the stock markets fuel economic growth through diversification, mobilizing and pooling of savings from different investors and availing them to companies for utilization, their ability to contribute optimally to the growth of an economy depends largely on their informational, operational and allocational efficiency. Underdeveloped or poorly functioning capital markets, characterized by illiquidity and high transaction costs, may deter investors, both domestic and foreign, from being active in the market. ${ }^{15}$

More financial intermediation is needed if incremental resources are to be allocated efficiently, because of constraints otherwise imposed on the growth of more profitable activities, especially when small. Banking comes to play a greater role in increasing resources for high-return activities and reducing the amount wasted in lower return ones. However, with healthy growth, competition is important, and both risk and return considerations are important. Hence, the financial system must grow in its ability to allocate resources ${ }^{16}$. As the economy grows, and grows more complex, the financial sector needs to keep pace. Banks need to grow and become more sophisticated in their ability to assess prospects for risks and returns; and, in parallel, there needs to be the development of other financial sources of investment capital. Sustained and rapid growth needs to be underpinned by a broadening and deepening of the financial system, capable of serving the needs of all parts of the economy. Those economies that have sustained rapid growth over the long term have experienced enormous structural change, as they have shifted from being predominantly rural and agricultural to a more urban, manufacturing-and-servicebased structure. ${ }^{17}$ This was certainly the history of the industrialized countries. As they grew in the eighteenth, nineteenth and twentieth centuries, their financial systems grew in depth and breadth. In the $19^{\text {th }}$ century, London achieved its status as the world's leading financial centre, because the financial sector had developed rapidly in order to serve the needs of British industry and British exporters. As it grew in order to support Britain's economic growth, it also became a major contributor to that growth and, for that matter, to growth in other parts of the world as it exported capital and financial skills. In the $20^{\text {th }}$ century, New York played a similar role in relation to the American economy. As New York developed as a financial centre to serve the needs of the dynamic and rapidly growing American economy, so it developed the skills and services that could themselves be exported ${ }^{18}$. Economists believe that the most important role of the financial sector in facilitating growth is to reduce information, enforcement, and

${ }_{12}$ Pyemo Afego (2012) Stimulating economic growth through the development of efficient capital markets, Business day

13 ibid

14 ibid

$15 \mathrm{ibid}$

${ }^{16} \mathrm{ibid}$

${ }^{17} \mathrm{ibid}$

${ }^{18}$ ibid 
transaction costs. This is achieved through a number of specific functions that the financial sector performs. The basic functions of financial sector are: to provide efficient payments mechanism for the whole economy; and intermediate between lenders and borrowers. These basic functions are the domain of banking institutions. Banks together with other financial intermediaries play a major role in facilitating the overall funding of the economy. Banks are major suppliers of credit to finance productive investment and other debt-financed activities. The banking system of a country in its sacrosanct role as an intermediary performs the crucial task of channeling resources from savings to investment; and the greater the financialization of savings, the greater the potential for the channeling of savings to productive activities and the more efficient the system, the better the mobilization of resources. Indeed, financial intermediaries perform five basic functions that affect the real economy. Levine (2004) and Zhuang, et al. (2009) identified and summarized five key functions that a financial system provides in facilitating growth:

- Mobilizing and pooling savings. When it is done efficiently, savings mobilization enhances technological innovation and resource allocation. The process of doing so from diverse savers is expensive. Thus, to mobilize savings, transaction costs and informational asymmetry must be contained. Financial systems that are more effective at agglomerating capital promote economic development by increasing savings, exploiting economies of scale, and overcoming investment indivisibilities. With large, indivisible projects, financial arrangements that mobilize savings from many diverse individuals and invest in a diversified portfolio of risky projects facilitate a reallocation of investment toward higher return activities with positive implications for economic growth.

- Producing information ex-ante about possible investments and allocating capital. Individual savers face high costs of acquiring and processing information on firms, managers, and market conditions, which could prevent capital from flowing to its best uses. Financial intermediaries reduce information costs through specialization and economies of scale and thereby improving resource allocation and the pace of growth. Only better information can engender the identification of appropriate production technologies and effective and efficient entrepreneurs. Stock markets may also stimulate the generation of information about firms. Expansion in markets and their growing liquidity, incentive agents to expend resources in researching firms because it is easier to profit from this information by trading in big and liquid markets.

- Monitoring investments and exerting corporate governance. The degree to which the owners of capital (shareholders and creditors) can effectively resolve the principal - agent problem has important implications for savings, decisions for allocating the savings, and their utilization. Good corporate governance helps improve the efficiency with which firms allocate and utilize resources and makes savers more willing to finance production and innovation. Zhuang et al. (2000) state that monitoring and disciplining by creditors (banks or bondholders), shareholder activism exercised by institutional investors (such as banks, pension funds, etc), threat of takeovers and market for corporate control, threat of insolvency, and capital market competition, among others, are effective mechanisms for strengthening corporate governance.

- Facilitating the trading, diversification and management of risks. Financial systems help mitigate the risks associated with individual projects, firms, industries, regions, and countries, etc. A financial system's ability to provide risk diversification services affects long-run economic growth by improving resource allocation and encouraging savings. Financial systems also enhance liquidity, reduce liquidity risks, increase investment in longer-term, higher return, but illiquid assets, and promote economic growth.

- Facilitating the exchange of goods and services. A financial system facilitates transactions in the economy, both providing and improving the payment systems and by reducing transaction and information costs associated with financial transactions. In this way specialization of production is encouraged, technological innovation is enhanced, and growth is ultimately achieved. Backward linkage effects occur from these productivity gains to financial market development and, thus, economic development can spur the development of the financial sector.

\section{Overview and Challenges of the Nigerian Financial Markets}

The Nigeria's financial market is relatively shallow and oligopolistic compared with its peers in emerging market economies (Report of the Financial Sector National Technical Working Group, Vision 20:2020, 2009). Although the financial market has witnessed some expansion in the review period, there are observed problems, which the market has to contend with. The overall performance of the market since 
inception has been mixed. In particular, as a propeller of economic growth and development, the financial market in Nigeria has performed below its potential (Nwosu \& Hamman, 2008). Prior to the establishment of the CBN in 1959, there was no formal or organized domestic money market in Nigeria, what existed then was an integral part of the London Money Market. The market operated by moving funds from the London money market to Nigeria for financing export produce. With the establishment of the CBN and the subsequent attainment of political independence in 1960, the CBN became involved in the active development of Nigeria's money market. The Nigerian financial market now constitutes a very important segment of the Nigeria's financial system and has assumed a more prominent role in the conduct of monetary policy. The market comprises the inter-bank funds market, short-term and longterm securities market. Since its formal emergence in the 1960s, until date, the Nigerian financial market has served the following major purposes: It has helped localize the credit base and has prevented the uncontrolled outflow of funds to foreign money markets. Importantly, the retention of funds within has contributed immensely to meeting domestic investment needs of the private sector. Another vital purpose of the Nigeria financial market is that it has facilitated the mobilization of funds to meet the credit requirement of government. The market, in addition, enables the banks to economize on their cash holding and adjust their liquidity positions as convenient as possible. It is also responsible for money creation through credit. The basic functions of the Nigeria financial market according to Nwosu \& Hamman (2008) is to facilitate the raising of short and long-term funds from the surplus sector to the deficit sector of the economy.

Despite the fundamental functions performed by the Nigerian financial markets (money and capital markets), the key issues facing the Nigerian financial market includes the following: dearth of instruments and lack of market breadth and depth which increase market volatility: inadequate skilled manpower resulting in low market development: the oligopolistic structure of the markets: dependence on government resulting in narrow instruments range and slow growth of the secondary market: information gap and asymmetry leading to market inefficiency: the market is relatively short (concentration on spot): the emergence of toxic assets as a result of global financial crises: inadequate risk management and corporate governance framework: and regulatory challenges. (See Report of the Financial Sector National Technical Working Group; Vision 20:2020, 2009). Furthermore, among the biggest challenges of the Nigeria money market is the creation of a highly liquid market in which investors can buy and sell with relative ease, where large transactions are consummated without significant changes in prices. This becomes necessary, given the backdrop that well-informed international investors generally consider the level of a market's liquidity before investing in such a market. They will only consider a market, which provides ease of entry and exit. Weak domestic payment systems have also hindered efficient liquidity management and have obstructed the development of the Nigerian financial market. In addition, the absence of efficient and cost effective systems for transferring ownership of the securities traded in the secondary market, or the funds to pay for them has obstructed market development or repurchases transactions. In comparison with financial markets of developed economies, the depth of the Nigerian financial market still needs restructuring. There are not enough investment outlets in the market. The appropriate legal framework needs to be put in place for the smooth introduction and operation of existing and new products. There is therefore the need to further empower the regulatory institutions to enable them check and nip in the bud any perceived or potential irregularity that may arise because of the introduction of new products or in the transaction of the existing ones. However, the prospect of the Nigerian financial Market is very bright. It has among other things, the potential to attract more investors into the country (See Nwosu \& Hamman 2008).

\section{Conclusion and Recommendations}

As much as the financial markets fuel economic growth through diversification, mobilising and pooling of savings from different investors and availing them to companies for utilisation, their ability to contribute optimally to the growth of an economy depends largely on their informational, operational and allocation efficiency. Underdeveloped or poorly functioning capital markets, characterised by illiquidity and high transaction costs, may deter investors, both domestic and foreign, from being active in the market. This is because inefficiencies in the price discovery process of financial assets imply less-than-optimal pricing and allocation of investment resources within the economy, thus undermining productive investment and growth. As such, most stock markets in the developing world, including Nigeria, face constraints, which result in serious implications such as liquidity issues, absence of trading activities, and a weakened 
investor base ${ }^{19}$. Therefore, if Nigeria seeks to join the ranks of the 20 most developed economies by year 2020, there is need for the nation's financial markets to evolve to a higher level of sophistication and depth to provide additional investment capital to meet the rapid expansion. The expansion in stock market activity across the country is necessary in view of the significant role financial markets play in the economic growth process. The study shows that the Nigeria's financial market is relatively shallow and oligopolistic compared with its peers in emerging market economies. Although, the markets have witnessed some expansion in recent times, but the overall performance has been below its potential. In particular, as propellers of economic development, the markets have not been able to meet their goals such as accelerating industrial development, promoting the rate of investment, generating employment opportunities, providing services that help accelerate poverty reduction, promoting human capital development, and accelerating agricultural productivity. This is because the market is plagued with several challenges such as dearth of instruments and lack of market breadth and depth which increase market volatility, inadequate skilled manpower resulting in low market development, the oligopolistic structure of the markets, dependence on government resulting in narrow instruments range and slow growth of the secondary market, information gap and asymmetry leading to market inefficiency, the emergence of toxic assets as a result of global financial crises, inadequate risk management and corporate governance framework, and regulatory challenges. There is therefore the need to diversify the economy from the petroleum sector to other sectors. Consequently, the financial markets should be effectively harnessed to set up development process in Nigeria. The financial sector should be reformed to serve as a tool of economic development and to uplift the welfare of the people of Nigeria. The capital market should be revitalized by the cooperation of all the stakeholders by making it an excellent capital market that would attract investment from local and foreign investors. In addition, the money market needs to deepen its product base such that short and medium term financing needs of the society can easily be met. The whole structure of the financial system should be link to the international financial markets. Policy makers should strive to remove every obstacle to the development of the financial markets and create the enabling environment needed for the financial markets to thrive with a view to serving as agent of growth and development. It is suggested that future research would investigate the role of Regulatory Bodies such as the Central Bank of Nigeria (CBN), Security and Exchange Commission (SEC), etc, on the development of Financial Markets in Nigeria. It is also necessary to examine the impact of Foreign Direct Investment (FDI) in the development of Financial Markets in Nigeria.

\section{References}

Adam, J. A. (1998). Financial Intermediation and Economic Growth: Evidence from Nigeria. Journal of Economic Management, 4(2).

Adebiyi, M. A. (2005). Capital Market performance and the Nigerian Economic Growth.

Agha, A. I., Ahmed, N., Mubarik, Y. A. \& Shah, H. (2005). Transmission Mechanism of Monetary Policy in Pakistan|I. SBP Research Bulletin, 1(2).

Ajakaiye, D. O. (2002). Banking Sector Reform and Economic Performance in Nigeria

Anyanwu, J. C. (1996). Monetary Economics. Lagos, Heinemann Educational Books (Nigeria) Plc.

Bagehot, W. (1873). Lombard Street in Fischer Stanley (2003) The Importance of Financial Markets in Economic Growth

Caporale, G. M. (2004). Stock Market Development and Economic Growth: The Causal Linkage. Journal of Economic Development, 29(1).

Ebhodaghe, J. U. (1996). Competition and Consolidation in the Nigerian Banking sector: A Regulator's perspective. Paper presented at the 1996 Budget Seminar organized by the Arthur Anderson, Lagos

Eichengreen, B. \& Favara, G. (2003). An Empirical Reassessment of the Relationship Between Finance and Growth, Washington, DC, IMF Working Paper WP/03/123.

Ekpo, H. A. (2008). The Nigerian Economy: Is it at the Crossroads? Presidential address delivered in Nigerian Economic Society, Abuja

Easterly, W. \& Ross, L. (1997). Africa's growth tragedy. Policies and ethnic divisions. Quarterly Journal of Economics, 112(2), 103-1250.

Fischer, S. (2003). The Importance of Financial Markets in Economic Growth.

Gelbard, E. \& Sérgio, P. L. (1999). Measuring financial development in Sub-Saharan Africa, IMF working paper 99/105.

19 Pyemo Afego (2012) Stimulating economic growth through the development of efficient capital markets 
Greenwood, J. \& Jovanovic, B. B. (1990). Financial Development Growth and the Distribution of Income. Goldsmith, R.W. (1969) Financial Structure and Development. New Haven, Conn Yale University Press Jalloh, M. (2009). The Role of Financial Markets in Economic Growth: Accra.

King, R. G. \& Levine, R. (1992). Finance and Growth, Schumpeter Might be Right.

Kolapo, F. T. \& Adaramola, A. O. (2012). The Impact of the Nigerian Capital Market on Economic Growth (1990-2010). International Journal of Developing Societies, 1(1), 11-19.

Krueger, O. A. (2006). Financial Markets and Economic Growth, Tokyo

Levine, R. (1996). Financial Development and Economic Growth: Views and Agenda. Journal of Economic Literature, 35, 688-726.

Levine, R. (1991). Law, Finance, and Economic Growth. Journal of Financial Intermediation, 8 (1-2), 8-35.

Levine, R. (2004). Bank-based or Market-based Financial Systems: Which is better? Journal of Financial Intermediation, 11(4), 398-428.

Levine, R. (2003). More on Finance and Growth: More Finance More Growth? Federal Reserve Bank of St. Louis Review, 85(4), 31-46.

Lucas, R. E. (1988). On the Mechanics of Economic Development.

McKinnon, R. I. (1973). Money and Capital in Economic Development; Washington D.C The Bookings institution.

Muhammad, S., Nadeem, A. \& Liaquat, A. (2003). Stock Market Development and Economic Growth: Causality in Pakistan. International Research Journal of Finance and Economics, 14, 1450-2887.

Nwosu, C. P. \& Hamman, H. M. (2008). The Nigerian Money Market: Issues and Challenges. Bullion, Publication of the Central Bank of Nigeria, 32(1).

Obstfeld, M. (1995). Risk Diversification and Growth.

Olofin, S. O. \& Udoma, J. A. (2011). Financial Structure and Economic Growth in Nigeria: A Macro econometric Approach: Ibadan

Omoruyi, S. E. (1991). The Financial Sector in Africa: Overview and Reforms in Economic Adjustment Programmes.

Osei, V. (2005). Does the Stock Market Matter in Ghana? A Granger-Causality Analysis, Bank of Ghana, WP/BOG-05/13.

Osinubi, T. S. (2002). Does Stock Market Promote Economic Growth In Nigeria

Pardy, R. (1992). Institutional Reform in Emerging Securities Markets, Policy Research Working Papers (Financial Policy and Systems), No. 907, World Bank.

Patrick, H. T. (1966). Financial development and economic growth in undeveloped countries. Economic Development and Cultural Change, 14, 429-447.

Pyemo, A. (2012). Stimulating economic growth through the development of efficient capital markets, Business day.

Saibu, M. O., Wakeel, A. I. \& Nwosu, P. I. (2009). Energy Prices and Macroeconomic Performance.

Schumpeter, J. A. (1934). The Theory of Economic Development: Cambridge M.A, Harvard University Press.

Senbet, L. \& Otchere, I. (2005). Financial Sector Reforms in Africa: Perspectives on Issues and Policies. Annual Bank Conference on Development Economics (The World Bank) 81-119.

Senhadji, A., Khan, M. \& Smith, B. D. (2000). Inflation and Financial Depth. IMF Working paper

Shaw, E. (1973). Financial Deepening in Economic Development: New York, Oxford University press.

Schoar, A. (2009). Lin Roundtable: Scale Matters. Free Exchange, Economist.com blogs. Available:http://www.economist.com/blogs/freeexchange/lin_roundtable. http://en.wikipedia.org/wiki/Economy_of_Nigeria 2012

Sobodu, O. \& Sobodu, A. (1999). Effects of stabilization Securities policy on Banking portfolio Behavior in Nigeria, Development Policy Centre Research Paper, Nigeria

Soyibo, A., Alashi, S. O. \& Ahmad, M. K. (1997). The extent and effectiveness of Bank supervision in Nigeria AERC Harare Zimbabwe

Thoma, M. (2009). Lin Roundtable: Small Banks Need Help. Free Exchange, Economist.com blogs. Available: http://www.economist.com/blogs/freeexchange/lin_roundtable

Todaro, M. P. \& Smith, S. C. (2009). Economic Development. 10 ${ }^{\text {th }}$ Edition, Addison-Wesley Publishers, New York

Umar, B. N. (2010). Stock Markets, Banks and Economic Growth: A Time -Series Evidence from South Africa.

Vision-20:2020. (2009). Report of the Financial Sector National Technical Working Group.

Zervos, S. \& Levine, R. (1998). Stock Market Development and Long-Run Growth. World Bank Economic Review, 10(2), 323-339. 
Zhuang, J., Gunatilake, H., Niimi, Y., Ehsan-Khan, M., Jiang, Y., Hasan, R., Khor, N., Lagman-Martin, A. S., Bracey, P. \& Huang, B. (2009). Financial Sector Development, Economic Growth and Poverty Reduction: A Literature Review\|, ADB Economics Working Paper Series No. 173 October Zingales, L. (2009). Lin Roundtable: Leave Room for Growth. Free Exchange, Economist.com blogs. Available: http://www.economist.com/blogs/freeexchange/lin_roundtable 